\title{
Antecedents of Social Entrepreneurship: Evidences from India
}

\author{
Dr Savitha Nair \\ Associate Professor, GRG School of Management Studies, India
}

\begin{abstract}
The term 'social entrepreneurship' is often used to describe the behaviour pursuing an explicit social mission; the purpose of which is delivering social benefit. The impactful solutions of social entrepreneurs are manifested in the form of social innovations involving new products, services, technologies and interventions leading to market transformations. In India, approximately 350 million people live below the poverty line, without adequate access to the basic necessities of life. There is presence of several other disadvantaged sections in the society making them vulnerable to social injustice, exploitation and suffering. Given the scale of the issue and the inherent limitations of Governmental interventions to reach and serve the needy, the need for social entrepreneurship is felt stronger than ever before. British Council (2016) stated that there are about 2 million social enterprises in India. Though there is a long history of social entrepreneurship in the country, the research in the field is still in its infancy. In this paper, we analyze the cases of select Indian social entrepreneurs and their ventures to understand the qualities, drivers and patterns of social entrepreneurship. The results explain the presence of personal, behavioural and social antecedents driving social pursuits. Social entrepreneurs are visionaries who seek opportunities, take risks, are passionate about their mission; and take persistent efforts in achieving impact. The insights lead to the development of hypotheses and framework for future empirical research and validation.
\end{abstract}

Keywords: Social Entrepreneur; Social Mission; Social Innovation; Social Impact; Social Change 